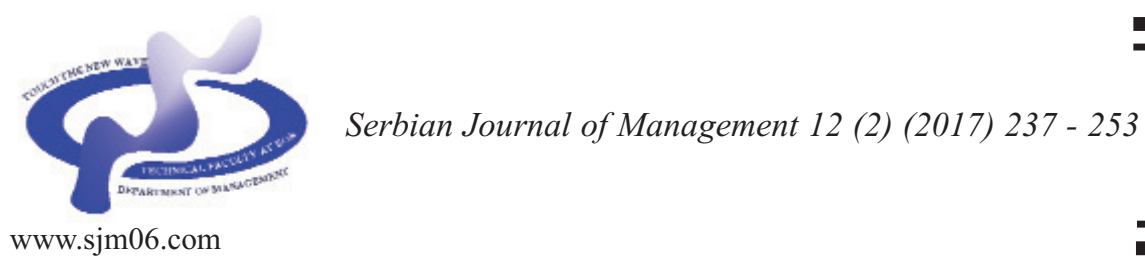

\title{
ANALYSIS OF BUDGET DEFICIT IN THE CANDIDATE COUNTRIES FOR EU MEMBERSHIP
}

\author{
Danijela Despotovića and Danijela Durkalićc*

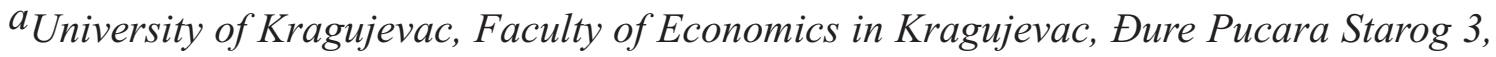 \\ Kragujevac, Serbia \\ ${ }^{b}$ University of Belgrade, Technical Faculty in Bor, Vojske Jugoslavije 12, Bor, Serbia
}

(Received 24 May 2017; accepted 03 August 2017)

\begin{abstract}
The problems of deficit and debt are the traditional drivers of the recession in the past. Due to the high impact of the budget deficit to increase in indebtedness and deterioration of a macroeconomic performance, the European Union in Maastricht Treaty and later in the Pact of Stability and Growth strictly defined fiscal criteria which the member states should adhere to. Fiscal criteria are particularly important when it comes to candidate countries for EU membership. The aim of this paper is that, through theoretical and empirical basis perform a comparative analysis of the budget deficit in EU countries and candidates for membership in the EU, to rank the 34 countries according to the criteria of public finances and to show the causality between the candidate countries for membership of the EU and EU member states.
\end{abstract}

Keywords: Budget deficit, European union, candidate countries, the PROMETHEE method

\section{INTRODUCTION}

Debt and budget deficit policy was studied in the past in almost all countries. Due to the occurrence of main debt crisis problems, this issue was once again brought to the fore by insisting on the fulfilment of the Maastricht criteria, which, in addition to monetary policy, give importance to fiscal policy.

Due to big problems and impact of crisis that spilled over from one country to another, like a domino effect, in terms of European integration, crisis in one country can deepen the negative effects in other countries. In this sense, research subject in this work focuses

\footnotetext{
* Corresponding author: ddurkalic@tfbor.bg.ac.rs
}

DOI: 10.5937/sjm12-14122 
on public finances of EU candidate countries and the member states of the European Union, with emphasis on budget deficit, as one of the Maastricht criteria. The aim of this study is to, with reference to well-founded theoretical sources, examine budget deficit and public finances through a panel of 34 countries, and investigate whether candidate countries have worse fiscal indicators.

The work is divided into three connected parts. The first part gives an overview of current literature regarding budget deficit of countries. The second part shows methodology to be used in the work. The third part will present comprehensive empirical research of budget deficit and public finances in general in the observed countries. This part shows basic statistical values of the observed parameters, as well as the causality of budget deficit and public debt phenomena. In this part of the work, countries will be ranked using the statistical program, Visual Promethee. Concluding remarks will point to final results of the work and their contribution.

\section{LITERATURE REVIEW}

Fiscal policy is a current issue that has for centuries been studied in economic literature. Since the Keynesian economic policy and aggregate demand, finding adequate approach to fiscal policy measures has faced controversy. Today, this topic is more than present in reality, because of adverse effects of fiscal parameters in most countries.

Fiscal rules have been in the focus of public and economic policy in recent years (Milesi-Ferretti, 2004). Researchers have dealt with the issue of whether fiscal rules lead to fiscal adjustment or encourage the use of the so-called creative accounting. Milesi-Ferretti considers probability of detecting creative accounting that depends precisely on budget transparency. The model studies the effects of budget rules on fiscal policy and examines whether these effects depend on fiscal distortions and the degree of budget transparency. The existence of a margin for creative accounting implies that the budget retains the ability to respond to cyclical shocks, even at the presence of budget rules.

Fiscal rules were particularly in the spotlight in the second half of the 1990s, when the Maastricht Treaty criteria stressed respect for fiscal rules of the budget deficit and public debt, leading the European Union to a single currency. In this sense, different authors analyze economic policy before joining the single European market. Weyerstrass (Weyerstrass, 2005) analyzes macroeconomic policy framework of Slovenia during the process of integration into the European Monetary Union. Using SLOPOL model (SLOvenian economic POLicy model), as a model of a small open economy, he shows that the best macroeconomic performance can be achieved with the crawling rate, not completely fixed against the euro. In this case, GDP growth rate does not vary significantly in relation to a flexible exchange rate, and inflation and unemployment are significantly lower, while the general government budget shows no significant changes.

In the context of European integration, Hallett and Lewis (Hallett \& Lewis, 2007) analyze debt and deficit of new Eurozone members, to come to the conclusion that in 2007 several countries had large primary deficit (Poland, Lithuania, and the Czech Republic), but no country violated the $3 \%$ 
criterion. Similarly, no country exceeded the $60 \%$ public debt criterion, although Hungary and Poland were close. There were predictions in how many years will countries exceed the fiscal criteria, assuming growth rate. Opportunistically speaking, their results suggest that those countries that already joined the ERM-II (Estonia, Slovenia, Latvia, and Lithuania) will have no problem to become members of the Eurozone, even if growth gets slower in these countries.

Andreev (Andreev, 2009) focuses on the current political situation in Bulgaria and Romania after their accession to the European Union. He compares the period of accession of these two countries to countries that joined the EU in 2004. However, the period of EU accession of Bulgaria and Romania took a different path, and this author in fact states that this was the difference in these countries compared to other countries that joined the European Union. An example is high corruption in both countries, which led to the paralysis of economic policy during the first year of membership. The main reason for this was the inability to quickly resolve political and social challenges and respond adequately to the Europeanization process. All this was the result of unfinished political and socioeconomic transformation in both countries.

The aim of the study conducted by Bolat et al. (2014) is to examine whether there is a link between budget deficit, current account deficit and net savings and the existence of the problem of "triple deficit" in 15 European countries in the period 2002-2013. Results reflect the existence of twin deficit relation in some countries, and triple deficit relation in some other. Batavia et al. (2013) presents a model of economic and financial implications for peripheral countries, called PIGS countries (Portugal, Ireland, Italy,
Greece, and Spain). Their model shows that membership in the European Monetary Union or even the upcoming membership triggered a huge influx of capital in this group of countries, increasing price and wage costs. Price growth in these nations reduced international competitiveness and net exports, while wage growth led to higher government expenditure and deteriorating government budget.

In the context of EU candidate countries, there is an interesting study by Mehilli and Zeneli (Mehilli \& Zeneli, 2013), who analyse the impact of the European integration policy on the management of public finances and regional economic integration. The authors investigate effectiveness of economic policy strategies and their impact on economic development. In the case of Albania, as a candidate country, the paper displays the foreign trade balance and the growing risks that may occur in Albania when interacting with the European Community. They come to the conclusion that, in developing countries, such as Albania, customs revenues account for $20 \%$ of public revenues, while these revenues in the European Union are significantly lower (from 0.1 to $4.5 \%$ ), due to liberal flows arising from contracts on free movement of goods. Given that Macedonia is a candidate country since 2005 , authors are concerned with the fulfilment of the Copenhagen criteria in this country. Particularly important are the economic criteria that Macedonia does not pay enough attention to (Azizi, 2015). It is pointed out that it is necessary to put emphasis on the functioning of the market economy, as well as the Macedonia's ability to cope with competitive pressure and market forces within the EU.

Foremny (Foremny, 2014) examines 
subnational deficit in the European Union and checks how fiscal rules and tax autonomy affect deficit among EU countries. With reference to a data set, this study measures tax autonomy and strength of fiscal rules at regional and local levels in the 15 countries of the European Union in the period before the crisis (1995-2008). Analysis of political variables to describe characteristics of the central government authority as an instrument of fiscal rules shows that effectiveness of fiscal rules and tax autonomy depend on constitutional structure. The results of the study point that fiscal rules reduce deficits only in unitary states.

Maltritz and Wüste (Maltritz \& Wüste, 2015) analyse fiscal determinants in the EU, and present budget balance indicators in 27 countries of the European Union in the period 1991 to 2011. The focus of their work is on effectiveness of fiscal rules and fiscal councils, as well as on the impact of membership in the European Monetary Union on the status and trends of fiscal adjustments. Special contribution of this study lies in the joint impact and interaction of fiscal rules on economic policy adjustments. The authors come conclude on a significant impact of fiscal rules in times of crisis. They point out that the existence of fiscal rules and the Stability and Growth Pact may in particular encourage "creative accounting" or manipulation with the government budget. Such manipulation is difficult to measure because of huge public amounts. A simple budget equation and stock-flow adjustment give the following iteration (Maltritz \& Wüste, 2015):

$\mathrm{B}_{\mathrm{t}}=\mathrm{B}_{\mathrm{t}-1}+\mathrm{D}_{\mathrm{t}} \rightarrow 0=\mathrm{B}_{\mathrm{t}}-\mathrm{B}_{\mathrm{t}-1}-\mathrm{D}_{\mathrm{t}}$
If $\mathrm{B}_{\mathrm{t}}$ is debt at time $\mathrm{t}$, the level of debt $\mathrm{B}_{t}$ is actually a debt level of the previous year plus the current budget deficit $\mathrm{D}_{t}$, which is the difference between total revenue and total expenditure. However, this basic budget equation is often not fulfilled in practice, leading to stock-flow adjustment (SFA), so the equation may be displayed as:

$\mathrm{SFA}=\mathrm{B}_{\mathrm{t}}-\mathrm{B}_{\mathrm{t}-1}-\mathrm{D}_{\mathrm{t}}$

This stock-flow adjustment is considered random residue, resulting from primary financial operations, such as debt insurance policies, privatization revenues, and exchange rate differences in the context of external debt. This random residue should annul over time, but also provides space for "creative public accounting", as the authors point out. They focus on the role of high fiscal deficit in the current European debt crisis, leading to review of previously used fiscal policies measures.

Role of the current fiscal policy is the subject of a number of papers that examine the role of fiscal rules in the current crisis and fiscal deficit. Considering this fact, Neaime (Neaime, 2015) examines sustainability of budget deficit and public debt in EU countries. Through a detailed empirical analysis of fiscal developments in the European Union over the last three decades, using the present value constraint (PVC), he presents the issue of sustainability of deficit and public debt in the European Union. Empirical study shows that budget deficit is re unsustainable within the chosen sample of EU countries (France, Germany, Greece, Ireland, Italy, Portugal, and Spain), with the exception of Germany. This set a new framework for the review of the role of fiscal policy, a change of its measures, and 
the introduction of appropriate austerity measures. Merkan deals with budget deficit in 18 OECD countries (Mercan, 2014), to conclude that budget deficit in these countries is poorly sustainable and that, in 2012, it exceeded 3\% of GDP. The paper points out that it is difficult to bring budget deficit in the state of sustainability, especially under unfavourable economic situation in terms of investment, low consumption, high foreign borrowing, and low private savings.

Pappas et al. (2016) examine the impact of the global financial crisis on stock markets in the European Union. Using data for the period 2001 to 2011, their study attempts to establish when each of the stock exchanges in Europe entered the crisis, how long each market remained in that mode, and how serious the crisis was. In this context, the authors point out that capital market varies among countries that have recently joined the EU and EU-15. Nevertheless, they point out that it takes a certain degree of integration of capital markets in this regard. Domino effect of the crisis is particularly important here, which can be best seen in the case of Greek debt crisis. The sovereign debt crisis in Greece very quickly turned into a crisis on a European scale (Kosmidou et al., 2015). What is more, fiscal policy management in these conditions becomes complex and multidimensional. For these reasons, Merkan (Mercan, 2014) points out the importance of precautions and sanctions, even though they are not welcome in society. Giray also deals with crisis period (Giray, 2015), ranking Turkey and the EU based on seven economic performance indicators before the crisis, during the crisis, and in the post-crisis period (GDP growth rate, inflation rate, public debt to GDP ratio, unemployment rate ( $\%$ of GDP), exports of goods and services (\% of GDP), imports of goods and services ( $\%$ of GDP), net flow of foreign direct investment ( $\%$ of GDP)). The results show that Luxembourg is a country with the best economic performance, and that Turkey is in the $25^{\text {th }}$ place according to the observed criteria. The worst ranking is recorded in cases of Italy and Greece. All these situations are enough to suggest that the issue of budget deficit and other macroeconomic parameters is very important, especially for the EU candidate countries, such as Albania, Bosnia and Herzegovina, Macedonia, Montenegro, Serbia, and Turkey.

\section{DATASET AND METHODOLOGY}

Analysis of the budget deficit and public finances of European Union candidates and the member states of the European Union will be carried out in several stages.

I. First, budget deficit to gross domestic product ratio will be considered as the basic criterion in budget deficit analysis, taking into account the Maastricht criteria. In this section, the analysis will focus on descriptive statistics of the parameters observed, with particular reference to pre-crisis (2000-2007) and post-crisis period (2008-2015).

II. The second part analyses techniques to explore the correlation between variables, as follows: public debt ( $\%$ of GDP) and budget deficit (\% of GDP). The correlation is observed from two angles: correlation of these two variables in the candidate countries compared to the European Union average, and correlation between the same variables before and after the crisis.

III. The third part of the analysis focuses on the ranking of the observed European Union countries and the candidate countries, 
based on basic fiscal indicators in these countries.

The European Union budget deficit data is taken from the Eurostat statistics, harmonized with the Treaty of Maastricht. Budget deficit data for the EU candidate countries is taken from the International Monetary Fund statistics, where deficit is calculated as the difference between public revenues and expenditures, which equals the difference between net acquisition of financial assets and net incurrence of liabilities. The budget deficit in both cases is calculated as a percentage of gross domestic product. Analysis of descriptive statistics and correlation will be done using the SPSS software package (Statistical analysis software package - SPSS Statistics), while the analysis to determine the ranking of countries before and after the crisis will be calculated using the Decision Lab software. Candidate countries below will be labelled CEU, while member states will simply be labelled EU.

\section{RESULTS AND DISCUSSION}

\subsection{Analysis of the budget deficit by Maastricht criteria}

The Maastricht Treaty, which entered into force in 1992, was a major step towards the creation of economic and monetary union in Europe. For countries to become members of the European Monetary Union (EMU), they were supposed to meet the fiscal and monetary criteria defined in the Treaty. Given that countries in the past faced big problems related to fiscal and monetary stability, the primary goal set was monetary - price stability. However, today, the situation is different, and all countries have a larger problem of fiscal instability, reflected in increasing public debt and budget deficit, while the monetary criteria in most cases are stable. For this purpose, in 1997, Stability and Growth Pact was created, which had the purpose of achieving price stability with sustainable growth in the long term. Nevertheless, its main argument was to achieve zero deficit in the long term in order to reach greater budget flexibility, in the case of asymmetric shocks (Soukiazis \& Castro, 2005). It is for reasons of flexibility that Stability and Growth Pact is taken as an adequate agreement that takes into account problems of individual countries, while, at the same time, analyses nominal and real convergence. Nominal convergence refers to the issues of fulfilment of the Maastricht criteria, while real convergence focuses more on growth of income per capita, living standard, productivity per employee, employment.

When the term convergence is mentioned, it is particularly interesting to reflect on the formation of nominal convergence criteria, relating to the level of budget deficit and public debt in the European Union. These fiscal criteria in particular are formed due to increasing budget deficit and public debt, which, over time, can undermine competitiveness and lead to the crowding out of private consumption and investment. As studies point out, the introduction of reference values in the form of budget deficit to GDP ratio of up to $3 \%$ and public debt to GDP ratio of up to $60 \%$ is arbitrary and not justified in economic theory and practice. These values are based on the simple equation (Bukowski, 2006):

$d=g \times b$

where $d$ - budget deficit (\% of GDP), $g-$ 
nominal GDP growth rate, and $b$ - public debt stabilization level ( $\%$ of GDP). Criteria is formed taking into account 5\% growth rate, and if public debt to GDP is still $60 \%$, simple conclusion is that the level of budget deficit is $3 \%$. However, if growth rate is $6 \%$, this simple Keynesian equation cannot be considered, as budget deficit will still be $3.6 \%$, and so on. Furthermore, in 1990, the average value of the EU public debt to GDP ratio might have been at the level of $60 \%$, and this is the reason why this value is adopted as the reference index. This equation is also criticized for being simple and based on the two variables of the budget deficit, so, in this context, the question of fulfilment of these criteria arises, which is empirically tested below.

Figure 1 shows the most significant measure of central tendency - arithmetic mean. It is now known that the criterion used is budget deficit ( $\%$ of GDP), and that, according to the Maastricht Treaty, this variable should not be lower than $3 \%$ for all countries wishing to join the European Monetary Union. Guided by this criterion, the question of CEU budget deficit and the EU budget deficit arises.

In the period before the crisis, analysed in terms of budget deficit from 2000 to 2007, the largest budget surplus was recorded in Baltic countries, Finland, Denmark, Sweden, Luxembourg. Of the CEU countries, Montenegro was the only one to record a surplus. On the other hand, there is budget deficit, as identified in most CEU and EU countries. Respecting the Maastricht convergence criteria, the highest mean value of the deficit before the crisis was recorded in Turkey, Greece, and Hungary. In addition, Malta, Slovakia, Poland, Portugal, Croatia, and the Czech Republic did not fulfil the Maastricht criteria before the crisis.

The situation after the crisis shows much different results. Figure 2 shows the arithmetic mean of budget deficit (\% of GDP) after the crisis in the period 2008 to 2015.

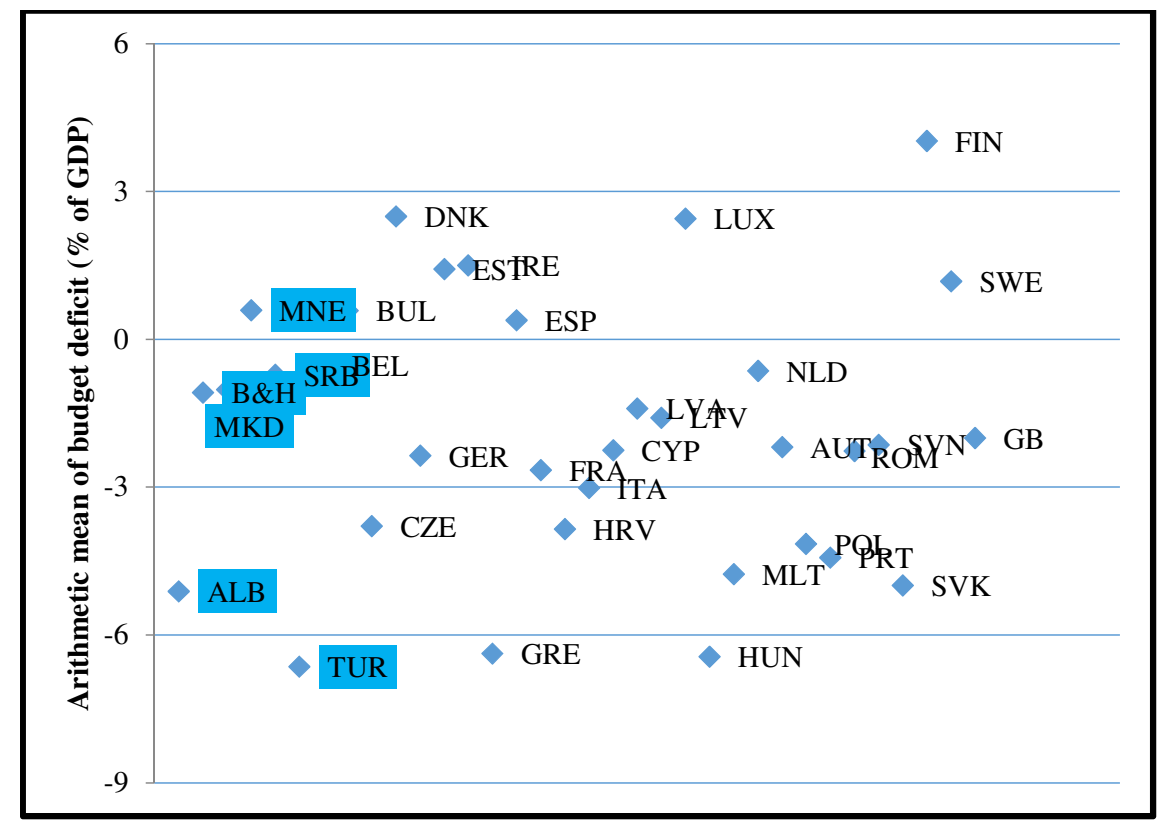

Source: Authors' calculation according to IMF and Eurostat data

Figure 1. Arithmetic mean of budget deficit (\% of GDP) before the crisis (2000-2007) 


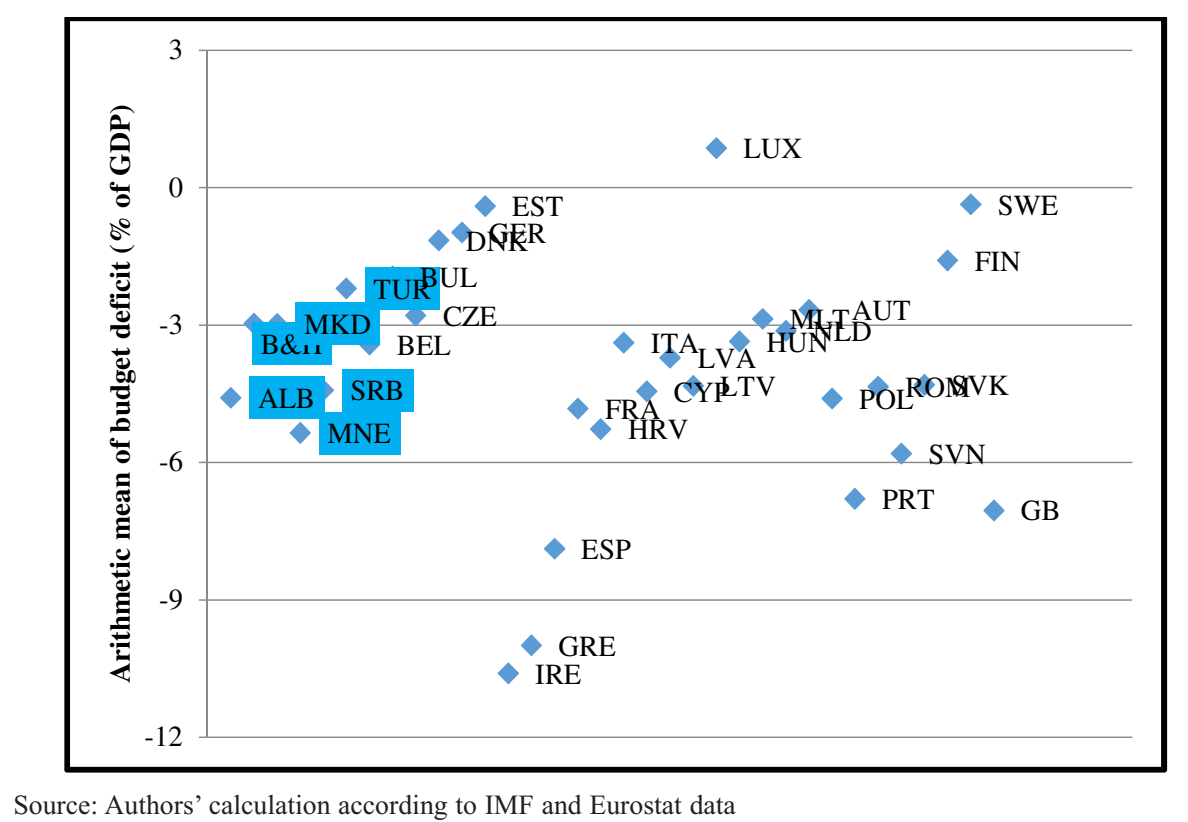

Figure 2. Arithmetic mean of budget deficit (\% of GDP) after the crisis (2008-2015)

With regard to dispersion, it is noted that countries are now in terms of budget deficit less dispersed, and mainly divided according to a number of similar levels of dispersion. It is interesting that Ireland is now in the worst position, ahead of Greece, although in the period before the crisis it had a budget surplus. Countries that had surplus before the crisis and after the crisis had a similar situation are Finland, Denmark, Sweden, Luxembourg. Nevertheless, the level of surplus declined significantly, compared to the period before the crisis. Concerning the candidate countries, mean value of the budget deficit as a $\%$ of GDP changed, above all, if Turkish deficit is observed, which significantly decreased. The remaining candidate countries were in the range of -3 to - $6 \%$, while, in the pre-crisis period, their mean value of budget deficit ranged from 0 to $-3 \%$ of GDP.

Table 1 gives basic descriptive statistics of budget deficit parameters (\% of GDP) in the period before and after the crisis. One can now clearly perceive growth of mean value in the period before and after the crisis. This change is even more noticeable in the EU countries than in the group of CEU countries. The lowest mean value before the crisis was recorded in Turkey and Albania, respectively. After the crisis, the lowest average value was recorded in Montenegro and Albania. On the other hand, EU countries drastically increased level of deficit. Variance in this case shows a measure of dispersion and probability statistics, relating to the said sigma convergence. With reference to data distance from the arithmetic mean, it varies a lot with the EU and the CEU countries. The maximum mean value before the crisis was positive in both groups of countries, while in times of crisis, even the maximum value was negative in both groups of countries.

Upon a review of basic statistical parameters, it is now easier via histogram to spot the differences between the two groups of countries observed before and after the crisis. The results of analysis are shown in Figure 3. 
Table 1. Descriptive statistics of budget deficit before and after the crisis

\begin{tabular}{lcccc}
\hline & \multicolumn{2}{c}{ CEU countries } & \multicolumn{2}{c}{ EU countries } \\
\hline & $\begin{array}{c}\text { Before the } \\
\text { crisis }\end{array}$ & $\begin{array}{c}\text { After the } \\
\text { crisis }\end{array}$ & $\begin{array}{c}\text { Before the } \\
\text { crisis }\end{array}$ & $\begin{array}{c}\text { After the } \\
\text { crisis }\end{array}$ \\
Mean & -2.33 & -3.75 & -1.70 & -3.97 \\
Standard error & 1.14 & 0.54 & 0.58 & 0.84 \\
Median & -2.23 & -3.63 & -1.68 & -3.70 \\
Standard deviation & 3.10 & 1.52 & 1.63 & 2.39 \\
Variance & 11.91 & 2.40 & 3.06 & 8.32 \\
Kurtosis & -0.92 & 0.25 & -0.32 & 0.29 \\
Skewness & -0.21 & -0.04 & -0.02 & -0.22 \\
Minimum & -6.56 & -6.06 & -4.04 & -7.83 \\
Maximum & 1.70 & -1.57 & 0.58 & -0.83 \\
Confidence level $(\mathbf{9 5 . 0 \% )}$ & 2.76 & 1.27 & 1.37 & 2.00 \\
\hline
\end{tabular}

Source: Authors' calculation according to IMF and Eurostat data

Figure 3 shows the said mean value of budget deficit (\% of GDP). At first glance, it is obvious that deficit is present both before and after the crisis in both groups of countries. Before the crisis, level of deficit was lower than in the period after the crisis. Difference in change of budget deficit rate before and after the crisis is higher in the EU
$(2.27 \%)$, while the difference in CEU countries is lower $(1.42 \%)$. If one takes into account convergence criterion of $3 \%$, in the pre-crisis period (2000-2007) both groups of countries fulfilled it, while in the period after the crisis (2008-2015), both groups of countries violated this criterion.

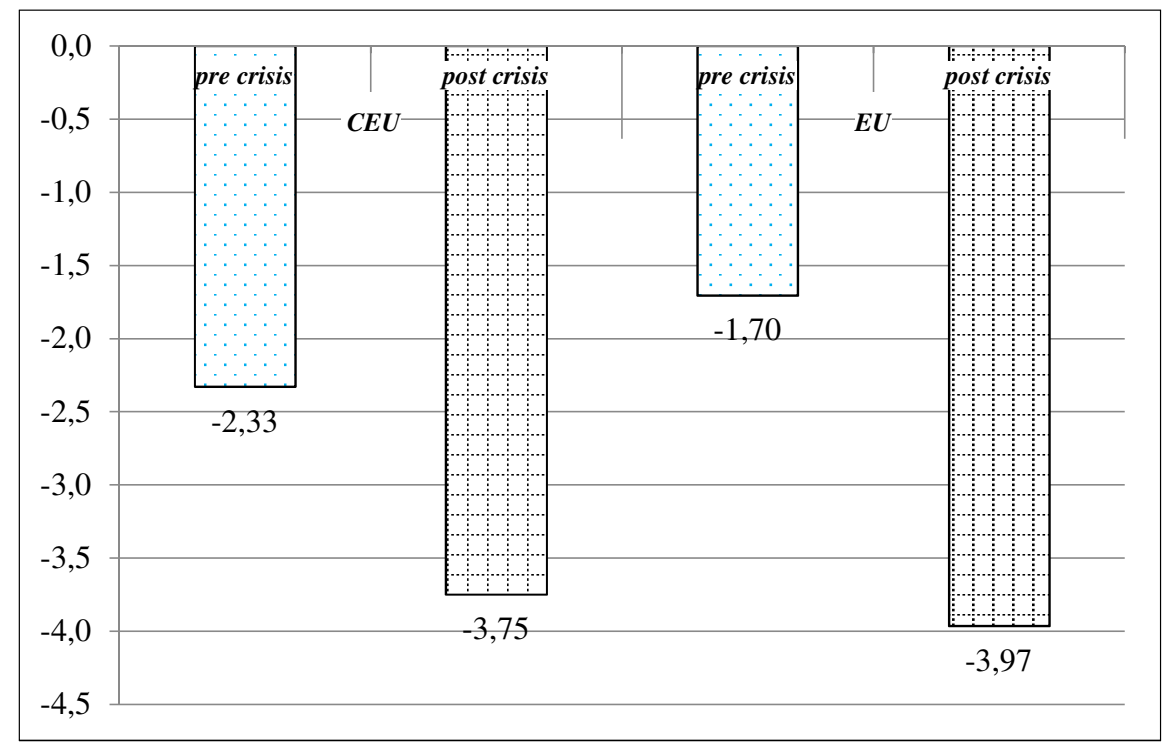

Source: Authors' calculation according to IMF and Eurostat data

Figure 3. Arithmetic mean of budget deficit (\% of GDP) before and after the crisis in CEU and EU 
4.2. Correlation between budget deficit and foreign debt of $E U$ candidate countries

Correlation is a practically useful statistical tool that shows the relationship between variables. The value of correlation between two variables is determined by measuring the correlation coefficient, which can range from -1 to 1 . Specifically, based on data on budget deficit and public debt in the European Union and candidate countries, the correlation coefficient between budget deficit (\% of GDP) in European Union and EU candidate countries will be calculated, as well as the correlation coefficient between public debt (\% of GDP) in the EU and EU candidate countries. Correlation of both indicators in all countries will be divided into time periods before the crisis and after the crisis.

To measure the intensity of correlation between these values, coefficients are calculated using the Statistical Package for the Social Sciences (SPSS). The objective of correlation analysis is to measure the intensity of correlation between the two sets of variables and test the statement that intensity is higher than expected just based on chance. The analysis will use Spearman's correlation coefficient for ease of calculation and suitability for use with data set with unknown distribution. The general rule applies to this coefficient, as well as to all values of correlation, meaning that the closer the value to one, the greater the correlation among the observed phenomena. Spearman's coefficient satisfies the conditions for use in the present case, there being unknown distribution, small sample, and relations between the two variables measured using ordinal scale (Croux \& Dehon, 2010). The intensity of correlation between the two variables is shown by the value of correlation coefficient, and sign in front of the coefficient indicates the direction of correlation. A value of 0 means that there is no correlation between the variables, while a value of 1 or -1 indicates complete correlation. The sign indicates the direction of correlation, i.e. whether both variables fall, or whether one grows and the other falls. There are different interpretations on the value of correlation, but one can be singled out, by which correlation is low if the correlation coefficient ranges from 0.10 to 0.29 , correlation is medium if the coefficient is in the range of 0.30 to 0.49 , and correlation is high for the value of coefficient from 0.50 to 1.0 (Pallant, 2008).

Table 2 shows correlation of two budget variables in the period before and after the crisis. During the pre-crisis period (20002007), the correlation coefficient of budget deficit (\% of GDP) in the candidate countries moved in the same direction as the budget deficit in the European Union (EU28), correlation being positive and medium in all countries, with the exception of Turkey, where there was strong and positive correlation between budget deficit in this country and that in the EU28. In the period after the crisis (2008-2015), in all the countries studied the correlation coefficient significantly declined, and the direction changed. In the post-crisis period, during growth of budget deficit in the EU28, it declined in Albania, Macedonia, and Serbia, while in Bosnia and Herzegovina, Turkey, and Montenegro, this coefficient had the same direction as the EU28.

The situation is particularly different when it comes to public debt as \% of GDP in the countries studied. What is common for all countries is very strong correlation between public debt indicators in the 
Table 2. Spearman's correlation coefficient between budget deficit (\% of GDP) and public debt (\% of GDP) in the European Union and the selected countries

\begin{tabular}{|c|c|c|c|c|}
\hline & \multicolumn{2}{|c|}{$\begin{array}{c}\text { Correlation between budget } \\
\text { deficit in the EU (\% of GDP) and } \\
\text { the respective country in a } \\
\text { period: }\end{array}$} & \multicolumn{2}{|c|}{$\begin{array}{c}\text { Correlation between public } \\
\text { debt in the EU ( } \% \text { of GDP) and } \\
\text { the respective country in a } \\
\text { period: }\end{array}$} \\
\hline & $\begin{array}{l}\text { (Before the } \\
\text { crisis) }\end{array}$ & $\begin{array}{l}\text { (After the } \\
\text { crisis) }\end{array}$ & $\begin{array}{l}\text { (Before the } \\
\text { crisis) }\end{array}$ & $\begin{array}{l}\text { (After the } \\
\text { crisis) }\end{array}$ \\
\hline EU28 & 1 & 1 & 1 & 1 \\
\hline Albania & 0.383 & -0.108 & 0.905 & 0.886 \\
\hline B\&H & 0.323 & 0.572 & 0,946 & 0.826 \\
\hline Macedonia & 0.383 & -0.253 & 0.881 & 0.994 \\
\hline Montenegro & - & 0.072 & - & 0.958 \\
\hline Serbia & 0.275 & $-0,012$ & 0.976 & 0.958 \\
\hline Turkey & 0.635 & 0.419 & 0.619 & -0.886 \\
\hline
\end{tabular}

Source: Authors' calculation using SPSS according to IMF and Eurostat data

European Union and the candidate countries. In the pre-crisis period (2000-2007), the correlation coefficient was moving in the same direction with the EU trend, i.e. public debt grew both in the EU and in the candidate countries, this coefficient being particularly strong with Albania, Bosnia and Herzegovina, and Serbia. The period after the crisis did not substantially change correlation between these countries. Correlation remained strong and positive in all countries except Turkey, which indicates that growth of public debt (\% of GDP) was present in the EU and EU candidate countries. Only with the growth of public debt in the EU, in Turkey this coefficient decreased.

\subsection{Comparative analysis of public finances in the $E U$ and candidate countries}

The initial step in this phase of research is the selection of macroeconomic indicators to be ranked. Based on its indicators, the World Bank provides a record of the following elements of country budgets (World Bank,
World Development Indicators: Central government finances):

1) Budget revenue ( $\%$ of GDP)

2) Budget expenditure ( $\%$ of GDP)

3) Budget deficit/surplus ( $\%$ of GDP)

4) Total public debt ( $\%$ of GDP)

5) Net investment in non-financial assets ( $\%$ of GDP)

6) Net acquisition of financial assets (\% of GDP)

7) Net incurrence of liabilities (\% of GDP), and

8) Interest rate payment ( $\%$ of budget revenue).

Due to unavailability of all values and indicators for each country, ranking will be done using the first four parameters. Given that IMF and World Bank statistics show net ratio of financial assets and liabilities through budget deficit also, there is no need for all the variables in the ranking. Candidate countries will be labelled with CEU, while the European Union will simply be labelled with EU.

Calculation of indicators was done using available statistical data of relevant organizations and institutions, and all data 
Table 3. Data sources

\begin{tabular}{|c|c|c|c|c|}
\hline & $\begin{array}{c}\text { Budget } \\
\text { revenues (\% } \\
\text { of GDP) }\end{array}$ & $\begin{array}{c}\text { Budget } \\
\text { expenditure } \\
(\% \text { of GDP) }\end{array}$ & $\begin{array}{c}\text { Budget deficit/surplus } \\
\text { (\% of GDP) }\end{array}$ & $\begin{array}{c}\text { Total public } \\
\text { debt (\% of } \\
\text { GDP) }\end{array}$ \\
\hline CEU & $\begin{array}{l}\text { IMF: General } \\
\text { government } \\
\text { total revenue } \\
\text { \%GDP }\end{array}$ & $\begin{array}{l}\text { IMF: General } \\
\text { government } \\
\text { total } \\
\text { expenditure } \\
\text { \%GDP }\end{array}$ & $\begin{array}{l}\text { Eurostat: Net lending } \\
(+) / \text { net borrowing }(-) \\
\text { IMF: Net lending }(+) / \\
\text { net borrowing (-) }\end{array}$ & $\begin{array}{l}\text { IMF: World } \\
\text { Economic } \\
\text { Outlook } \\
\text { Database: } \\
\text { General } \\
\text { government } \\
\text { gross debt }\end{array}$ \\
\hline
\end{tabular}

Source: Authors' calculation

sources were used to obtain 4 indicators expressed as a percent. The obtained statistical data will be used in the next step of analysis - data ranking and determining the ranking of individual countries or groups of countries. Data ranking will use Decision Lab 2000 software package.

Given that the issue of budget deficit of countries falls within multi-criteria analysis domain, a set of criteria needs to be reduced to a single criterion, in order to properly compare data. PROMETHEE \& GAIA methodology offers such a possibility for comparative analysis, developed by the Canadian company Visual Decision (Brans \& Mareschal, 1986). As an adequate method for solving multi-criteria problems, PROMETHEE GAIA methodology aims to rank a finite set of alternatives (in this case, countries) based on the criteria that should be maximized or minimized. In the case of this study, the criteria are the mentioned indicators.

Preference ranking is the most preferred method for making multi-criteria decisions (Tomić et al., 2011). For each alternative (country), value of alternative is calculated and expressed by preference, which has positive and negative flow. On the basis of the calculated preferences, net flow of preferences is calculated, which synthesizes all the indicators and, on this basis, ranks the given alternatives (countries). Each of $n$ alternatives is characterized by $\mathrm{k}$ criteria, which are chosen depending on the observed problem and the factors influencing the final decision. Criteria differ among themselves, first of all, by the unit of measure and whether this criterion should be maximized or minimized (Nikolić et al., 2009).

In this paper, alternatives are the observed countries. Ranking will be made in the context of the two post-crisis scenarios: 2008 and 2014. The weights assigned to the criteria are equal and amount to $25 \%$, in order to avoid subjective assessment of significance of each indicator. Also, depending on preference objective function, the first and third criteria will be maximized, while the remaining criteria have a direction of preference going towards minimizing. Distribution and weights of indicators are shown in Table 4. Budget deficit has max direction of preference because in every country there is a deficit, so they have a negative value, but as surplus is desirable, the direction of preference is $\max$.

Based on the analysis of preference function formation and net flow of preferences, ranking of countries can be made. The comparative analysis will include the candidate countries as well as indicators 
Table 4. Distribution of weights of the used indicators

\begin{tabular}{clcc}
\hline $\begin{array}{c}\text { Criterion } \\
\text { label }\end{array}$ & \multicolumn{1}{c}{ Name of the criterion } & $\begin{array}{c}\text { Weight } \\
\text { coefficient }\end{array}$ & $\begin{array}{c}\text { Direction of } \\
\text { preference }\end{array}$ \\
\hline $\mathbf{C}_{\boldsymbol{1}}$ & Budget revenue (\% of GDP) & $25.00 \%$ & $\mathrm{max}$. \\
$\mathbf{C}_{\boldsymbol{2}}$ & Budget expenditure (\% of GDP) & $25.00 \%$ & $\mathrm{~min}$. \\
$\mathbf{C}_{\boldsymbol{3}}$ & Budget deficit/surplus (\% of GDP) & $25.00 \%$ & $\mathrm{max}$. \\
$\mathbf{C}_{\boldsymbol{4}}$ & Total public debt (\% of GDP) & $25.00 \%$ & $\mathrm{~min}$. \\
\hline
\end{tabular}

Source: Authors' calculation

of the European Union and the European Monetary Union, to make comparison compatible with this regional integration. Upon synthesizing four criteria used to observe the state of public finances, the ranking of countries is shown through two scenarios. The first scenario relates to the ranking of countries in 2008, while the second scenario relates to the same countries and their position in the comparison matrix in 2014.

Figure 4 shows that the ranking of countries is such that of all 34 countries surveyed, Luxembourg occupies the leading position. Right behind are Bulgaria and Finland. For Luxembourg, as a country of tax heaven and the most developed financial system, this position is not surprising. In addition, within the observed indicators, this Luxembourg position is mostly the result of budget surplus of $3.4 \%$ in 2008 . In addition to Luxembourg, the only countries that achieved budget surplus in 2008 are Bulgaria and Sweden, which led Bulgaria to the $2^{\text {nd }}$ position and Sweden to $7^{\text {th }}$ (due to the public debt of $36.68 \%$ of GDP in 2008). Bulgaria, as the new EU member state since 2007, also had low public debt, which was $14.5 \%$ of GDP this year. It can be pointed out that, in 2008 , some of the candidate countries were in favourable positions, compared to some EU countries.

Macedonia was ranked fifth, Montenegro $12^{\text {th }}$, and Serbia $13^{\text {th }}$. Turkey was ranked $20^{\text {th }}$, while Albania was the worst of all candidate countries and occupied the $28^{\text {th }}$ position. Behind Albania there are Malta, Portugal, United Kingdom, Hungary, Ireland, and Greece, as the worst. The worst
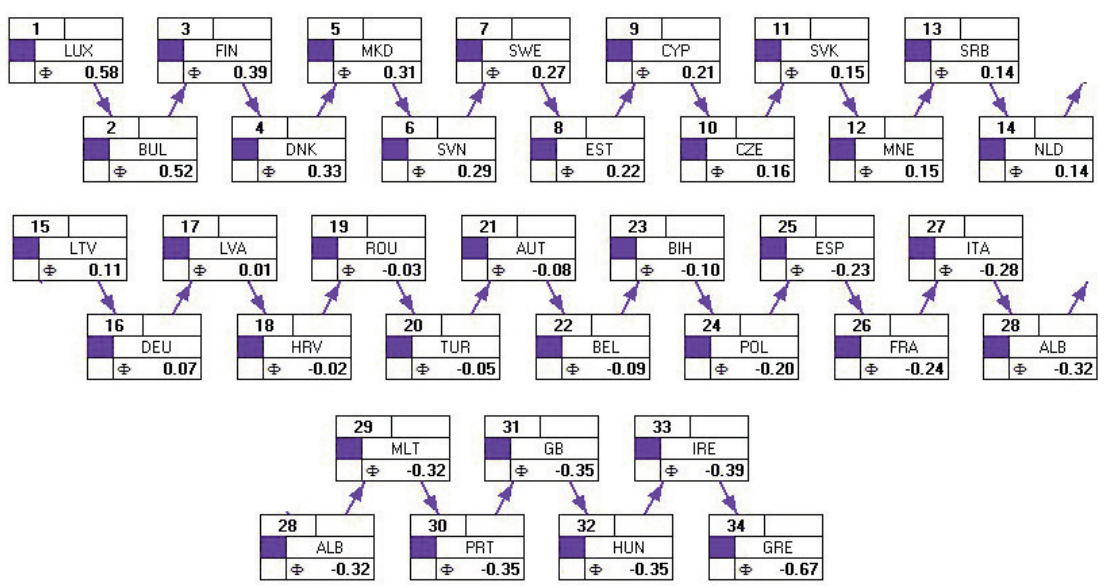

Source: Authors' calculation based on data processing using Decision Lab software

Figure 4. First scenario: Ranking of countries according to public finances in 2008 
ranked countries are precisely countries that were affected by debt crisis. The last position of Greece was to highest public debt of $109.42 \%$ of GDP in 2008, as well as budget deficit of $10.2 \%$ of GDP. In addition to Greece, Ireland also exceeded the budgetary deficit limit defined by the Maastricht criteria (it recorded a budget deficit of $7 \%$ of GDP in 2008), leading it to $33^{\text {rd }}$ position. Hungary was in $32^{\text {nd }}$ position precisely because of high public debt, which was $71.65 \%$ of GDP.

The situation in 2014 significantly changed. Only Luxembourg still retained its leading position. For these reasons, which remained relevant in 2014, Luxembourg, despite crisis, maintained budget surplus of $1.5 \%$ of GDP in 2014. Estonia, due to the achieved surplus of $0.70 \%$ of GDP and public debt of only $10.37 \%$ of GDP, moved from the $8^{\text {th }}$ position to the $2^{\text {nd }}$ position. The result of Turkey is surprising, which reached the $3^{\text {rd }}$ position in 2014 , compared to the 20 th position it had in 2008. The reason for this is a decrease in the budget deficit (from $-2.72 \%$ of GDP in 2008 to $-0.92 \%$ of GDP in 2014) and public debt (from $39.98 \%$ of GDP in 2008 to $33.52 \%$ of GDP in 2014).

The second-ranked was Estonia, while
Turkey even reached the third position in 2014, compared to the $20^{\text {th }}$ position it had in 2008. Montenegro and Macedonia were in $14^{\text {th }}$ and $16^{\text {th }}$ position, respectively, while Bosnia was in $11^{\text {th }}$ position. Serbia worsened the situation and fell from $11^{\text {th }}$ to $29^{\text {th }}$ position. The reason for this is high increase in the budget deficit (from $-1.89 \%$ GDP in 2008 to $-6.23 \%$ of GDP in 2014) and public debt (from $32.38 \%$ of GDP in 2008 to as much as $72.01 \%$ of GDP in 2014). Behind Serbia, poorer quality of public finances was recorded in Greece, United Kingdom, Cyprus, Spain, and Portugal, respectively. Regarding these countries, even in 2014, they failed to cope with the debt crisis that was reflected in enormously high public debt in Portugal (from $71.67 \%$ of GDP in 2008 to as much as $130.17 \%$ of GDP in 2014) and the budget deficit (from $-3.8 \%$ of GDP in 2008 to $-7.2 \%$ of GDP in 2014). In Spain, public debt increased more than double, from $39.40 \%$ of GDP in 2008 to as much as $99.29 \%$ of GDP in 2014. It is surprising for Cyprus, which moved from the $9^{\text {th }}$ position to the $32^{\text {nd }}$ position. As with other worst ranked countries, the reason is high public debt growth (from $44.57 \%$ of GDP in 2008

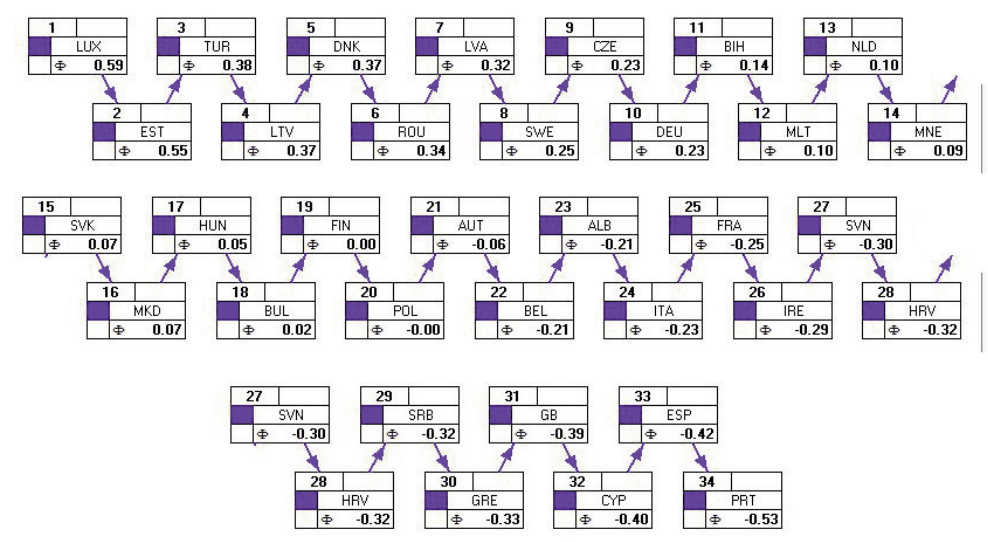

Source: Authors' calculation based on data processing using Decision Lab software

Figure 5. Second scenario: Ranking of countries according to public finances in 2014 
to as much as $108.19 \%$ of GDP in 2014) and the budget deficit (with a surplus of $0.9 \%$ of GDP in 2008 to a deficit of $-8.8 \%$ of GDP in 2014).

\section{CONCLUSION}

In contemporary economic conditions and with the emergence of economic integration, the issue of budget deficit is one of the main problems of public finances. The extent of the problem is reflected in the fact that, today, there is no country without public debt, and nearly all the observed countries have budget deficit. So, absolutely all observed countries are characterized by deterioration of public finances.

This paper makes an adequate theoretical, scientific, and social contribution to management and definition of the state of public finances, in particular through the ranking of countries according to the criteria of deficit, debt, budget revenue, and budget expenditure. Encompassing theoretical framework, the paper first gives an overview of literature and the emergence of deficit in countries. Using public finance indicators, scientific contribution is reflected in the statistical ranking of parameters and determining the ranking of individual countries. Correlation of candidate countries and EU member states is observed. Ranking and descriptive statistics reflect the issue of public finances, indicating that the candidate countries in relation to individual EU countries are in a much better position in terms of public finances. However, these countries have a more stable macroeconomic policy and monetary framework, and find it "easier" to cope with deficit.

The over-consumption of the country in relation to production can lead and has led in the past to serious problem in the functioning of countries. If consumption is higher than production, then the country will resort to borrowing beyond the borders of its own country, which creates a long-term unsustainable problem. This paper makes a distinction, in the original way, between other works in this field that show the state of public finances, budget deficit and public debt. The work provides the empirical basis of the reasons for a better or worse position of the country in two time horizons. Particular focus is on the presentation of public finance data after the crisis period, which creates a realistic picture of the consequences of the financial crisis on public finances in different countries. This work presents clear interdependence between financial and fiscal sectors of the economy. When it comes to newer EU Member States, the work is a significant addition to Andreev's results, and confirms Azizi's results on deterioration of public finances.

Future research should further focus on correlation analysis. The analysis can include more data, when the World Bank, which keeps a record of data, creates opportunities for that. Also, it might be interesting to complement this analysis with regression analysis and analysis of variance. Nominal convergence can be complemented by real convergence, which can represent an appropriate scientific contribution in the future.

\section{Acknowledgements}

The authors feel indebted to the company Visual Decision Inc. Montreal, Canada, for software package Decision Lab 2000 provided to them free of charge. 
АНАЛИЗА БУЏЕТСКОГ ДЕФИЦИТА ЗЕМАЉА КАНДИДАТА ЗА

ЧЛАНСТВО У ЕУ

\section{Данијела Деспотовић и Данијела Дуркалић}

\section{Извод}

Проблеми дефицита и дуга традиционално представљају покретаче рецесија у прошлости. Због високих утицаја буџетског дефицита на повећање задужености и погоршање макрекономских перформанси, Европска унија је Мастрихтским уговором, а касније и Пактом о стабилности и расту строго дефинисала фискалне критеријуме којих би земље чланице требало да се придржавају. Фискални критеријуми су нарочито важни када су у питању земље кандидати за чланство у Европској унији. Циљ овог рада је да, кроз теоријску и емпиријску основу изврши компаративну анализу буџетског дефицита земаља Европске уније и кандидата за чланство у Европску унију, да рангира ове 34 земље према критеријуму јавних финансија и да укаже на каузалитет између земаља кандидата за чланство у ЕУ и чланица ЕУ.

Кључне речи: буџетски дефицит, Европска унија, земље кандидати, PROMETHEЕ метод

\section{References}

Andreev, S.A. (2009). The unbearable lightness of membership: Bulgaria and Romania after the 2007 EU accession. Communist and Post-Communist Studies, 42 (3), 375-393.

Azizi, A. (2015). Economic Criteria for EU Membership and Legislation on Economic Reforms in Macedonia. Procedia Economics and Finance, 26, 709-716.

Batavia, B., Nandakumar, P., \& Wague, C. (2013). Export stagnation and budget deficits in the peripheral EU nations with EMU membership. The Journal of Economic Asymmetries, 10 (2), 94-100.

Brans, J.P., Mareschal, B. (1986). How to Decide with PROMETHEE GAIA Software, ULB and VUB Brussels Universitie, Vrije Universiteit Brussel, 1-5.

Bolat, S., Değirmen, S., \& Şengönül, A.
(2014). Does Triple Deficits Have (Un) Stable Causality for the EU Members? Evidence from Bootstrap-Corrected Causality Tests. Procedia Economics and Finance, 16, 603-612.

Bukowski, S. (2006). The Maastricht convergence criteria and economic growth in the EMU. Quaderni del Dipartimento di Economia, Finanza e Statistica, 24, 1-19.

Croux, C., Dehon, C. (2010). Influence functions of the Spearman and Kendall correlation measures. Statistical methods \& applications, 19 (4), 497-515.

Decision Lab 2000 (V.1.01.0388) Visual Decision Inc. Montreal, Canada.

Eurostat, Government Finance Statistics: http://ec.europa.eu/eurostat/statisticsexplained/index.php/Government_finance_s tatistics

Foremny, D. (2014). Sub-national deficits in European countries: The impact of fiscal 
rules and tax autonomy. European Journal of Political Economy, 34, 86-110.

Giray, S. (2015). Comparing the Effect of Global Crisis 2008 on the Economic Performance of Turkey with EU Member States: Factor Analysis and TOPSIS Application. Eurasian Journal of Economics and Finance, 3 (1), 1-12.

Hallett, A.H., \& Lewis, J. (2007). Debt, deficits, and the accession of the new member States to the Euro. European Journal of Political Economy, 23 (2), 316-337.

IMF, World Economic Outlook (WEO)

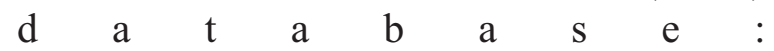
https://www.imf.org/external/pubs/ft/weo/20 17/01/weodata/weoselco.aspx?g=2001\&sg= All+countries

Kosmidou, K.V., Kousenidis, D.V., \& Negakis, C.I. (2015). The impact of the EU/ECB/IMF bailout programs on the financial and real sectors of the ASE during the Greek sovereign crisis. Journal of Banking \& Finance, 50, 440-454.

Maltritz, D., \& Wüste, S. (2015). Determinants of budget deficits in Europe: The role and relations of fiscal rules, fiscal councils, creative accounting and the Euro. Economic Modelling, 48, 222-236.

Milesi-Ferretti, G.M. (2004). Good, bad or ugly? On the effects of fiscal rules with creative accounting. Journal of Public Economics, 88 (1), 377-394.

Mehilli, T., \& Zeneli, F. (2013). Strategies of Albanian Economy to Meet EU Economic Policies. Procedia-Social and Behavioral Sciences, 99, 26-35.

Mercan, M. (2014). Budget deficits sustainable? An empirical analysis for OECD countries. Procedia-Social and Behavioral Sciences, 131, 258-263.

Nikolić, Đ., Jovanović, I., Mihajlović, I., \& Živković, Ž. (2009). Multi-criteria ranking of copper concentrates according to their
quality-An element of environmental management in the vicinity of copper-Smelting complex in Bor, Serbia. Journal of environmental management, 91 (2), 509-515.

Neaime, S. (2015). Sustainability of budget deficits and public debts in selected European Union countries. The Journal of Economic Asymmetries, 12 (1), 1-21.

Pappas, V., Ingham, H., Izzeldin, M., \& Steele, G. (2016). Will the crisis "tear us apart"? Evidence from the EU. International Review of Financial Analysis, 46, 346-360.

Pallant, J., (2008). SPSS Survival Manual: A Step by Step Guide to Data Analysis Using SPSS for Windows, Open University Press, United Kingdom.

Soukiazis, E., \& Castro, V. (2005). How the Maastricht criteria and the Stability and Growth Pact affected real convergence in the European Union: A panel data analysis. Journal of Policy Modeling, 27 (3), 385-399.

SPSS Inc. Released 2009. PASW Statistics for Windows, Version 18.0. Chicago: SPSS Inc.

Tomić, V., Marinković, Z., Janošević, D. (2011). PROMETHEE method implementation with multi-criteria decisions. Facta universitatis-series: Mechanical Engineering, 9 (2), 193-202.

Weyerstrass, K. (2005). An optimal macroeconomic policy mix for Slovenia after EU accession. IFAC Proceedings Volumes, 38 (1), 71-76.

World Bank, World Development Indicators: Central government finances: http://wdi.worldbank.org/table/4.12 